Meta

Journal des traducteurs

Translators' Journal

\title{
Linguistic Patterns and Devices in American Jewish Humorous Discourse
}

\section{Jacob L. Ornstein-Galicia}

Volume 34, numéro 1, mars 1989

Humour et traduction

Humour and Translation

URI : https://id.erudit.org/iderudit/002787ar

DOI : https://doi.org/10.7202/002787ar

Aller au sommaire du numéro

Éditeur(s)

Les Presses de l'Université de Montréal

ISSN

0026-0452 (imprimé)

1492-1421 (numérique)

Découvrir la revue

Citer cet article

Ornstein-Galicia, J. L. (1989). Linguistic Patterns and Devices in American Jewish Humorous Discourse. Meta, 34(1), 125-127.

https://doi.org/10.7202/002787ar d'utilisation que vous pouvez consulter en ligne.

https://apropos.erudit.org/fr/usagers/politique-dutilisation/ 


\section{LINGUISTIC PATTERNS AND DEVICES IN AMERICAN JEWISH HUMOROUS DISCOURSE}

JACOB L. ORNSTEIN-GALICIA U.T.E.P., El Paso, Texas

\section{A : GENERAL BACKGROUND}

Of the more than hundred immigrant languages in America, very few have greatly influenced English, if one excepts a few names of ethnic foods and the like. A decided exception is Yiddish, brought here from the shtetls of Eastern Europe, and portrayed with considerable accuracy by The Fiddler on the Roof, based on Sholem Aleichem's stories. Yiddish developed from Middle High German dialects, spoken by Jews invited to settle in Slavic lands by rulers who wished to develop commerce and industry. Constantly in contact with speakers of other languages, Yiddish speakers borrowed heavily, much of the process involving cultural loans, and items of "affective" nature. In addition, depending upon the speaker, Yiddish may contain ten to twenty percent loans from Hebrew, the language of ritual, and Jewish identity.

As noted, Yiddish heavily influenced American English in the domain of humorous, colloquial English. The process of transmission of Yiddish to English is quite clear, coming from contact between Jews and Gentiles in the media, arts, and show business, as well as in commerce and industry. Although Yiddish to a large extent (there are exceptions) went the way of other immigrant languages - being displaced by English in a generation or so - its linguistic legacy lives on with an extraordinary vigor. Much of this may be attributed to the image stereotypically of Jews as clever, resourceful, saucy, irreverent, and able to land on their feet when adversity strikes. This, of course, is an allure based on a mystique, depending of stereotypes, comparable to some extent to Black English, of which a sub set of lexicon has entered colloquial American English. The motivations for Black English, nevertheless, rest on other reasons which cannot be covered here for lack of space.

It will be seen that Yiddish linguistic influence has even penetrated the domain of syntax, ordinarily the most resistant area to borrowing, and even one aspect of phonology. Unfortunately, studies of contacts between immigrant languages have been mostly limited to "grocery lists" of loans, rephonemicized and relexified. The borrowing process, actually, is capable of revealing much about inter-ethnic perceptions, and begs for new studies sensitive to socio-psychological dynamics.

\section{B : PATTERNS OF BORROWING FROM YIDDISH}

It can be estimated that several hundred Yiddish lexemes and phrases are employed, in varying degrees, by American English speakers, wishing to supply additional dimensions or nuances to their discourse at certain points. We again stress that this involves not gap-filling but affective considerations and the desire to add a touch of gallows humor, impudence, cockiness, smart-aleck overtones, and in a word, to inform the discourse with a sense of "chic" Yiddish-style. 
Briefly reviewing the patterns and devices employed, we call attention to:

1. LEXICON - Ordinarily the borrowed item is rephonemicized, although since English is also a Germanic language, radical phonemic changes may not occur, although modifications are pretty certain to occur at the phonetic and sub-phonetic levels. One source, although linguistically naive, is Leo Rosten's The Joys of Yiddish, which is quite comprehensive. Another, linguistically accurate, is Wentworth and Flexner's Dictionary of American Slang. Typical borrowings are: klutz "clod", schlock "junky article or disagreeable person", maven "expert". As occurs universally in the borrowing process, semantic changes sometimes occur. Perhaps one of the most striking is schmuck, roughly equivalent to "jerk" in colloquial American English, but originally signifying in Yiddish "penis". An example of a widely current calque or loan translation is bottom line, corresponding to Yiddish untershte shire, and also "You should live so long", based in Yiddish, "Du zolst azoy lang leben".

2. PHONOLOGY - The consonant cluster /sh/ followed by a consonant, rare or non-existent in English, is borrowed from Yiddish in which this combination occurs particularly in terms of derision, of a "put-down" nature, such as schlemiel "person who fouls things up", schlump "slob", schlep "an inept or clumsy person". Accordingly, this combination is used creatively for mocking or derisive effect, as in "Money, shmoney, just so he loves his mother !" [Editor's Note: Based on this pattern there is an ironic oneliner: "Oedipus, Shmoedipus, so long as he loves his mother!"]

More subtle than the segmental loans above is the borrowing of at least one intonational pattern, by non-Jews who have been in close contact with Jewish Americans. Oversimplified, this consists of a series of rises, explained by some observers as originating in the cantillation or sing-song recitation of Hebrew prayers. This may be illustrated as follows :

2And you're 3 that's 2 1telling me work of

3. SYNTAX - The most prominent pattern borrowed in this area is one apparently borrowed in turn originally by Yiddish from Slavic languages. As most Slavic languages have explicit case systems, word order permits beginning a sentence with the object. Let us illustrate this by the following example:

Him I don't like.

Other, more subtle patterns occur, but have been little studied apparently.

4. DISCOURSE - Again we are dealing with subtle phenomena, and I will merely say that there is an identifiable paragraph or supra-sentence pattern distinguished by a series of simple sentences punctuated orally by Yiddish adverbs and phrases connoting exaggerated emotion, surprise, dejection, elation and other effects. 
5. RHETORICAL DEVICES - A large inventory of rhetorical devices are available from Yiddish including, particularly, hyperbole, exaggeration, minimization, litotes and others. It is common to introduce a theme by such expressions also as: "I'm going to tell you something", "Let me tell you something", "Look".

6. KINESICS - Although converging in large cities with kinemes also common to other "Mediterranean" peoples, such as Italians, Greeks, Syrian-Lebanese, people in show business and elsewhere appear to have borrowed some typically Yiddish gestures such as frequent brisk shoulder shrugging, flinging both hands outward and raising them while looking upward, forcing body contact, sometimes by pressing a finger or hand into some part of the interlocutor's anatomy, standing spatially considerably closer than the distances which are proper according to Anglo-Saxon constraints. Ethnic proxemics have been little studied in sociolinguistics.

7. CONCLUDING REMARKS - It should be reiterated that the amount of influence upon American English suggested above is enormous, when one considers that the Jewish population of the United States is barely above three percent, and the vast majority of these are monolingual English speakers. Nevertheless, the case of YiddishEnglish contact has many psycho-sociological implications which have mostly been taken for granted. The subject of Jewish humor itself, of which there is a great deal in the entertainment world, is, of course, a closely related topic, and one which subsumes the strictly linguistic aspects discussed here.

\section{BIBLIOGRAPHY}

FISHMAN, Joshua A. (1982) : Never Say Die! A Thousand of Yiddish in Jewish Life and Letters, The Hague, Mouton.

ORNSTEIN, Jacob and David GOLD (1976): "A Note on the Slavic Impact on Yiddish", Orbis, 25:1, pp. 121-128.

ROSTEN, Leo (1968) : The Joys of Yiddish, New York, Pocket Books.

ROSTEN, Leo (1982): Hooray for Yiddish, New York, Simon and Schuster.

STEINMETZ, Sol (1981): "Jewish English in the United States", American Speech, 56:1 (Spring), pp. 3-16.

WEINREICH, Uriel (1954) : Languages in Contact, New York, Linguistic Circle of New York.

WENTWORTH, Harold and Stuart BERG FLEXNER, eds. (1975) : Dictionary of American Slang, Second Edition, New York, Thomas Y. Crowell. 